\title{
СУБАРАХНОЇДАЛЬНІ КРОВОВИЛИВИ РІЗНОЇ ЕТІОЛОГІЇ: ОСОБЛИВОСТІ КЛІНІЧНОЇ СИМПТОМАТИКИ ТА МЕДИЧНОГО СПОСТЕРЕЖЕННЯ
}

\author{
г. Я. Угрин
}

Тернопільська обласна комунальна клінічна психоневрологічна лікарня

У статті розглянуто клінічні особливості субарахноїдальних крововиливів різної етіології, які визначають напрямки медсестринського спостереження у гострому періоді у відділенні інтенсивної терапії.

\section{SOME ASPECTS OF THE ASSESMENTS OF THE PATIENTS WITH SUBARACHNOID HEMORRHAGE}

\author{
H. Ya. Uhryn \\ Ternopil Regional Municipal Clinical Psychoneurological Hospital
}

The article aduced the clinical signs of subarachnoid hemorrhages of different etiology which have influence on the direction of the nursing care and assessments in acute period in intensive unit care.

Вступ. Субарахноїдальний крововилив (САК) - це клінічний синдром, що відрізняється відомою нозологічною самостійністю і зумовлений різними етіологічними чинниками. Спонтанним САК вважається крововилив нетравматичної природи [1]. Виділяють вісім етіологічних варіантів САК, найчастішими з яких $\epsilon$ аневризматичний, гіпертензивний та атеросклеротичний. Аневризми судин головного мозку - це слабкі, опуклі місця на стінці артерій головного мозку [2]. Частота аневризм складає: у жінок - 12,2\%, у чоловіків - 7,6 \% на 100 тис. населення в рік. Щорічний ризик розриву аневризми становить $1-5 \%$, протягом життя - 10-30\%. Факторами ризику, які спричиняють розрив аневризми і виникнення САК, вважаються: артеріальна гіпертензія, тютюнокуріння, хронічний алкоголізм, надмірна маса тіла, вживання наркотиків. Виділяють декілька різновидів САК залежно від масивності крововиливу і виходу крові за межі субарахноїдального простору: субарахноїдально-паренхіматозний, субарахноїдально-вентрикулярний, субарахноїдальнопаренхіматозно-вентрикулярний крововилив. Всі вказані форми крововиливів можуть призводити до оклюзії лікворних шляхів, дислокації мозку і формування оклюзійно-гідроцефального синдрому.

Розрив аневризми може трапитися при будь-якомуії розмірі, протенайчастіше, коли вона більша, ніж 3-5 мм.

(с) Г. Я. Угрин, 2015
Ризик розриву аневризми та виникнення САК позитивно корелює з розміром аневризми, гіпертонією та тютюнокурінням. Ризик САК лінійно збільшується з віком від 25 до 60 років з найвищим піком захворюваності у 50-60 років [5]. САК потенційно небезпечний для життя пацієнта своїми ускладненнями, такими, як: церебральний вазоспазм, рецидив крововиливу, набряк мозку та оклюзійна гідроцефалія [3, 4].

У даній роботі проведено порівняльний аналіз клініко-параклінічних проявів аневризматичних та спонтанних САК.

Основна частина. Проведено комплексне обстеження 72 хворих у гострому періоді САК (29 (40,3 \%) чоловіків та $43(59,7$ \%) жінки), які перебували на стаціонарному лікуванні у ВІТі та інсультному відділенні Тернопільської обласної комунальної клінічної психоневрологічної лікарні. Вік хворих склав від 25 до 58 років (у середньому - $(42,4 \pm 6,4)$ р.). Хворих молодого віку (до 45 р.) було 37 (51,4 \%), середнього віку - (від 45 до 60 р.) було 35 (48,6 \%). У всіх пацієнтів діагноз САК був верифікований за допомогою спіральної комп'ютерної томографії (Astelon 4, Toshiba) або МРТ. При негативному результаті під час проведення нейровізуалізаційних методів за допомогою дослідження цереброспінальної рідини. Клініко-неврологічне обстеження хворих проводили після ретельного ознайомлення 3 історією хвороби, медичною документацією і даних 
неврологічного огляду, результати фіксували в спеціальному протоколі. Під час госпіталізації хворі підлягали стандартній процедурі клінічного обстеження, яка включала детальне соматичне і неврологічне дослідження, оцінку менінгеального та загальномозкового синдрому, розладів ковтання.

Для клінічної оцінки тяжкості САК використовували шкалу Ханта-Хесcа (W. Hunt i R. Hess), і шкалу Всесвітньої федерації нейрохірургів (WFNS). Тяжкість СAK на КТ головного мозку визначали за шкалою Фішера.

У 63 (87,5 \%) хворих діагностовано лише САК, ще у $9(12,5 \%)$ - субарахноїдально-вентрикулярний крововилив.

Відповідно до етіології у 43 (59,7 \%) спостерігався САКу результаті аномалії аневризми мозкових судин: у $40(55,6 \%)$ - розрив аневризми мозкових судин, у $3(4,2 \%)$ - розрив артеріовенозної мальформації.
У решти 29 (40,3 \%) діагностовано спонтанний САК. За локалізацією аневризми виявлялися у наступних судинах: задня сполучна артерія - у 21 (29,2 \%), ВСА у $12(16,7 \%)$, СМА - у 7 (9,7 \%), ПМА - у 3 (4,2\%) хворих. Розміри аневризм до 5 мм мали 6 (8,3\%), 5-10 мм $15(20,8 \%)$ та більше 10 мм - у $19(26,4 \%)$ хворих. У середньому розміри аневризм склали $(6,2 \pm 0,4)$ мм. У пацієнтів молодого віку в 35 (94,6 \%) випадках виявлено аневризму мозкових судин, у 2 (5,4 \%) - ГХ. У хворих середнього віку в $8(11,1 \%)$ випадках мала місце аневризма та АВМ, у решти - спонтанний САК.

з супутньої патології в пацієнтів зі спонтанним САК спостерігалася: гіпертонічна хвороба - у 18 (25,0\%), атеросклероз - у 7 (9,7\%), поєднання гіпертонії та атеросклерозу - у 4 (5,6\%) хворих.

Фактори ризику, виявлені у обстежуваних пацієнтів, наведено в таблиці 1.

Таблиця 1. Фактори ризику в хворих із САК

\begin{tabular}{|l|c|c|}
\hline \multicolumn{1}{|c|}{ Фактори } & Абс. & $\%$ \\
\hline Артеріальна гіпертензія & 32 & 44,4 \\
\hline Тютюнокуріння & 29 & 40,3 \\
\hline Зловживання алкоголем & 26 & 36,1 \\
\hline Застосування оральних контрацептивів & 7 & 9,7 \\
\hline Гіперхолестеринемія & 11 & 15,3 \\
\hline
\end{tabular}

Як видно з наведених даних, найбільш значимими для розвитку САК були АГ, тютюнокуріння та зловживання алкоголем.

У 65 (90,3\%) хворих спостерігався гострий початок захворювання. У 7 (9,7 \%) відмічалися передвісники у вигляді нападів мігренеподібного головного болю, нападів затерпання та транзиторної слабкості у кінцівках.

За шкалою Ханта-Хесса у 15 (20,8\%) хворих діагностовано I ст. тяжкості, у 27 (37,5 \%) - II ст., у 24 (33,3\%) III ст. та у $6(8,3 \%)$ - IV ст. тяжкості САК. У пацієнтів зі змішаним субарахноїдально-вентрикулярним крововиливом за шкалою Ханта-Хесса у 5 (55,6 \%) випадках мав місце CAK IV ст. тяжкості, у 4 (44,4\%) - III ст. Тобто, змішані субарахноїдально-вентрикулярні крововиливи були тяжчими, ніж тільки САК.

щодо віковихгруп встановлено, що тяжчий ступінь САК спостерігався у хворих молодого віку порівняно з пацієнтами 45-60 р. Так само, більша тяжкість САК виявлена в осіб чоловічої статі порівняно з жінками.

У всіх хворих виявлено ознаки менінгеального синдрому: ригідність потиличних м'язів, симптом Керніга, болючість при пальпації трігемінальних, окципітальних точок, виличний феномен Бехтерева.
У 39 (52,2 \%) хворих спостерігалися ознаки загальної гіперестезії з фото- та фонофобією.

Лише у 2 (2,8 \%) хворих була відсутня загальномозкова симптоматика, у решти $70(97,2 \%)$ пацієнтів мав місце загальномозковий синдром різного ступеня вираженості. У 69 (95,8 \%) хворих спостерігався виражений головний біль, у 35 (48,6\%) - розгорнутий судомний напад, у 42 (58,3 \%) - нудота з повторним блюванням. При поступленні порушення свідомості виявлено у 22 (30,6\%) хворих. У $12(16,6 \%)$ з цих хворих діагностовано оглушення, у $6(8,3 \%)$ - сопор та ще у 4 (5,6 \%) - кома I ст. За шкалою Глазго у середньому рівень свідомості становив $(13,9 \pm 0,2)$ бала. Пацієнти зі змішаним субарахноїдально-вентрикулярним крововиливом мали більший ступінь порушення свідомості порівняно з ізольованим САК: відповідно $(12,6 \pm 0,3)$ та $(14,1 \pm 0,2)$ бала. Одночасно глибші розлади свідомості також виявлялися у хворих до 45 р. порівняно 3 хворими середнього віку: $(12,8 \pm 0,4)$ та $(13,9 \pm 0,5)$ бала.

Вогнищева неврологічна симптоматика в дебюті САК спостерігалася у 9 (12,5\%) хворих. Вона переважно проявлялася при аневризмі задньої сполучної артерії. у $6(8,3 \%)$ хворих виявлено окорухові порушення: 
птоз, мідріаз, косину; у 5 (6,9\%) - рефлекторнопірамідну недостатність.

Усім пацієнтам було проведено МРТ головного мозку в судинному режимі. У 69 (95,8 \%) хворих виявлено ознаки САК. Це проявлялося наявністю крові у міжпівкульній щілині, в ділянці сільвієвої борозни, у 4 (5,6 \%) хворих з масивним САК - у цистернах мозку. В 9 (12,5 \%) хворих було виявлено ознаки субарахноїдально-вентрикулярного крововиливу, ще в 1 - субарахноїдально-паренхіматозного. У $3(4,2 \%)$ хворих ознаки САК при нейровізуалізаційних методах обстеження були відсутні. Діагноз САК у них було підтверджено результатами люмбальної пункції. Відсутність явищ САК на МРТ була пов'язана з малими розмірами аневризми і наявністю невеликої кількості крові у субарахноїдальному просторі.

За модифікованою шкалою Фішера на КТ головного мозку зміни 1 класу виявлено у 28 (38,9\%), 2 у $5(6,9 \%), 3$ - у 32 (44,4 \%), 4 - у 4 (5,6 \%) хворих. Тобто в обстежуваних хворих за даними КТ у пацієнтів переважала помірна кількість крові у субарахноїдальному просторі.

За даними транскраніального дуплексного сканування (ТКДС) у 32 (44,4\%) хворих мав місце вазоспазм, хоча лише у $14(19,4$ \%) з них вазоспазм був ускладнений розвитком ішемічного інсульту. Вогнище ішемії локалізувалося у правій півкулі у $8(11,1 \%)$, у лівій у $6(8,3 \%)$ хворих.

Серед інших ускладнень у 5 (6,9\%) хворих спостерігався повторний САК з незакріпленої аневризми, що супроводжувалося погіршенням стану хворого з наростанням загальномозкового синдрому: виражений головний біль, нудота, блювання, в 1 пацієнта виник розгорнутий епілептичний напад та поглиблення розладів свідомості. Явища вираженої внутрішньочерепної гіпертензії спостерігали у 3 (4,2\%) хворих.

У $5(6,9 \%)$ пацієнтів спостерігалися ознаки набряку мозку з ознаками вторинного стовбурового синдрому: окоруховими порушеннями, розладами дихання (періодичне дихання за типом Чейна-Стокса) та незначущими розладами серцево-судинної діяльності.

Встановлено, що біоелектрична активність мозку в гострий період САК характеризувалася загально- мозковими змінами, наявністю поліморфної білатеральносинхронної активностірізногоступеня вираження у більшості хворих. Частота виявлення патологічної повільнохвильової активності збільшувалася із 42,8 \% при помірному ступені тяжкості церебрального вазоспазму (ЦВС) до 68,4 \% за вираженого ЦВС. ЕЕГзміни у хворих із вираженим ЦВС характеризувалися зниженням амплітуди та дезорганізованістю alphaритму, грубим поліморфним характером theta- та delta-активності. Розподіл типів ЕЕГ-змін у гострий період САК відрізнявся залежно від тяжкості ЦВС: під час вираженого ступеня спазму в 73,6 \% випадків реєстрували III і IV типи, при помірному ступені у 90,4 \% випадків II та III типи. Встановлено достовірний зв'язок між реєстрацією IV типу ЕЕГ-змін і розвитком вогнищевих неврологічних порушень, формуванням вогнищ ішемії за даними комп'ютерної томографії мозку. Тобто при розвитку відтермінованих ішемічних порушень у хворих із аневризматичним САК відносилися також зміни ЕЕГ, що відповідали IV типу, які також можна включити до комплексу прогностичних несприятливих чинників.

Булопроведено порівняльний аналіз пацієнтів з аневризматичним та спонтанним САК. Отримані результати засвідчили, що оцінка за шкалою WFNS, оцінка за шкалою Фішера і тривалість перебування у ВІТі були значно вищими у пацієнтів із САК аневризматичної етіології. Наслідки аневризматичного САКбули значно несприятливішими порівняноз пацієнтами зі спонтанним САК(табл. 2). П'ятеро хворих померли протягом гострого періоду САК від церебральних ускладнень. Причиною смерті у трьох із них була повторна кровотеча з незакріпленої аневризми, і двоє хворих померли в результаті розвитку некоригованої внутрішньочерепної гіпертензії. ще один хворий помер від екстракраніальних причин (пневмонії з наступним розвитком синдрому системної запальної відповіді та респіраторного дистрес-синдрому з летальною дихальною недостатністю на 11 добупісля аневризматичного САК.

За шкалою Фішера при аневризматичних САК достовірно частіше спостерігався САК 3 класу порівняно з іншими пацієнтами, що склало 23 хворих проти $9(p<0,05)$.

ТаблицЯ 2. Порівняльна характеристика хворих із аневризматичним та спонтанним САК

\begin{tabular}{|l|c|c|}
\hline \multicolumn{1}{|c|}{ Показник } & Аневризматичний САК & Спонтанний САК \\
\hline Шкала Фішера, бали & $2,9 \pm 0,2$ & $2,3 \pm 0,3$ \\
\hline Шкала WFNS, бали & $3,1 \pm 0,1$ & $2,2 \pm 0,2$ \\
\hline Перебування у BITi, дні & $14,2 \pm 0,9$ & $11,1 \pm 1,3$ \\
\hline
\end{tabular}


Частота ЦВС з наступними ускладненнями у вигляді ішемічного інсульту також була достовірно вищою у хворих з аневризматичним САК $(p<0,05)$. При аневризматичному САК кількість пацієнтів з ішемічними ускладненнями становила 11 (25,6\%), при спонтанному - $3(10,3 \%)$ випадки.

При аневризматичному САК достовірно частіше реєструвалися ЕЕГ-зміни IV типу, що можна пояснити частішим розвитком вазоспазму в даній групі хворих.

\section{ЛITEPATУРА}

1. Крылов В. В. Хирургическое лечение больных с нетравматическими внутримозговыми кровоизлияниями / В. В. Крылов // Журнал неврологии и психиатрии. - 2007. Спецвыпуск «Инсульт». - С. 42-43.

2. Cerebral aneurysms. In Hickey J. V. (Ed.), The clinical practice of neurological and neurosurgical nursing (6th ed.) D. A. Buckley, J. V. Hickey Philadelphia, PA: Lippincott, Williams, \& Wilkins, 2009. - P. 536-367.
Висновки. 1. Субарахноїдальні крововиливи аневризматичної етіології характеризуються більш тяжким, ніж спонтанні, перебігом, частішими та тяжчими ускладненнями, гіршим функціональним результатом та вищою летальністю у гострому періоді.

2. Медичні сестри ВІТ, які здійснюють спостереження за хворими з аневризматичним САК, повинні вміти оцінити соматичний та неврологічний стан пацієнтів, використовувати уніфіковані шкали для попередження, діагностики та лікування ускладнень.

3. Janjua N. Cerebral vasospasm after subarachnoid hemorrhage / N. Janjua, S. Mayer // Current Opinion in Critical Care. - 2003. - Vol. 9(2). - P. 113-119.

4. Suarez J. I. Aneurysmal subarachnoid hemorrhage / J. I.Suarez, R. W. Tarr, W. R. Selman // N Engl J Med. - 2006. Vol. 354(4). - P. 387-396.

5. Unruptured intrac-ranial aneurysms: Natural history, clinical outcome, and risks of surgical and endovascular treatment / D. O. Wiebers, J. P. Whisnant, Huston [et al.] // Lancet. - 2003. - Vol. 362(9378). - P. 103-110.

Отримано 19.11.15 